\title{
ANALISA KESELAMATAN DAN KESEHATAN 2KERJA DALAM MENGIDENTIFIKASI DAMPAK TINGKAT KEBISINGAN TERHADAP PEKERJA PADA PLTD KELAPA LIMA MERAUKE
}

\author{
Peter Sahupala ${ }^{1}$, Cipto $^{2}$ \\ 1,2 Jurusan Teknik Mesin, Fakultas Teknik, Universitas Musamus Merauke. \\ Email: ${ }^{2}$ cipto@unmus.ac.id,
}

\begin{abstract}
ABSTRAK
Kebisingan yaitu merupakan salah satu permasalahan terhadap kesehatan pekerja, yang selalu muncul pada dunia industri di Indonesia yang menggunakan tenaga penggerak motor Disel. Dalam berkembangnya dunia industri pembangkit daya dibidang kelistrikan yang di sebabkan semakin banyaknya tenaga kerja yang terpapar terhadap kebisingan yang intensitas yang semakin tingginya maka dapat menyebabkan pada gangguan fisiologis terhadap pekerja dan penyebab terganggunya pendengaran pekerja.

Kebisingan merupakan salah satu faktor bahaya terhadap kesehatan pekerja dan dapat merusak sel saraf terhadap pendengaran pekerja, di mana dapat mempengaruhi pendengaran yaitu melalui gelombang longitudinal yang dapat menimbulkan getaran dari sumber kebisingan di mana bunyi dan gelombang yang akan merambat melalui udara atau penghantar lainnya.

Sehubungan dengan hitungan korelasi maka terdapat nilai koefisien korelasi setiap item yang akan ditunjukan bagaimana derajat validitas item tersebut. dan untuk menentukan kelayakan item maka kuesioner digunakan untuk dilakukan uji signifikansi koefisien korelasi. Item dapat dikatakan valid saat nilai signifikansi lebih dari $0.05(>0.05)$ lalu kemudian disamakan dengan $r$ tabel dan menurut jumlah responden $(\mathrm{N})$. Berdasarkan hasil penelitian yang telah dijelaskan sebelumnya, maka dapat disimpukan bahwa secara persial hubungan alat pelindung Diri berpengaruh positif dan signifikan pendengaran bagi petugas/operator di PLTD Kelapa Lima Merauke.
\end{abstract}

Kata kunci : Dampak Tingkat kebisingan 


\section{PENDAHULUAN}

Kebisingan yaitu merupakan salah satu permasalahan terhadap kesehatan pekerja, yang selalu muncul pada dunia industri di Indonesia yang menggunakan tenaga penggerak motor Disel. Dalam berkembangnya dunia industri pembangkit daya dibidang kelistrikan yang di sebabkan semakin banyaknya tenaga kerja yang terpapar terhadap kebisingan yang intensitas yang semakin tingginya maka dapat menyebabkan pada gangguan fisiologis terhadap pekerja dan penyebab terganggunya pendengaran pekerja. PT. Perusahaan Listrik Negara (PLN) Kelapa lima Merauke sektor Pembangkit Listrik Tenaga Disel (PLTD) di mana Perusahaan yang menggunakan tenaga Disel sebagai pembangkit tenaga listrik di kabupaten Merauke dan sekitarnya.

Berdasarkan keputusan Menteri tenagakerja Nomor : KEP-51/MEN/1999 yaitu tentang nilai-nilai ambang batas kebisingan ( NAB) adapun keseimbangan di tempat kerja yang di tetapkan sebasar kurang dari $85(\mathrm{~dB})$ maka nilai yang dintetukan pada ambang batas kebisingan di tempat kerja yaitu intensitasnya yang tinggi dan merupakan nilai rata-rata yang masih dapat di terima tenaga kerja dalam perusahan.

Kebisingan juga mempengaruhi pendengaran terhadap kariyawan di PT PLN (Persero) Kelapa Lima Merauke. adapun pengaruh yang signifikan antara intensitas bising terhadap tekanan suara yang mengganggu pendengaran pekerja. Maka dari itu ada perubahan tekanan darah yang pengaruh terhadap faktor usia pekerja, atau jenis kelamin adapun faktor yang mempengaruhi yaitu, faktor genetik, faktor bobot badan, faktor kegiatan fisik, faktor denyut jantung ${ }^{[1]}$.

sedangkan di Indonesia berkisar antara 31-50\%. Akibatnya dari tinnginya kebisingan ini diatas NAB memberikan efek yang sangat mengganggu aktifitas terhadap pekerja, adapun pengaruh terhadap indra pendengaran yang resikonya mengalami ketulian atau penurunan daya pendengaran, dan juga dapat terjadi secara perlahan pada waktu yang cukup lama, Gangguan pendengaran juga dapat menurunkan seimbangan akibat kerja yang belum mendapatkan perhatian sepenuhnya, namun pada gangguan ini menempati urutan pertama di dalam daftar penyakit akibat kerja di Amerika dan Eropa dengan proporsi 36\%.

Sistem pendengaran merupakan salah satu dari indra manusia, yang jika mengalami gangguan pendengaran maka dari itu proses komunikasi antar pekerja akan sulit dilakukan. Kemudian pada saat berinteraksi terhadap orang yang mengalami gangguan pendengaran maka akan di sebabkan perasaan frustasi, tidak sabar atau marah dan rasa iba terhadap orang tersebut, yanag diketahui bahwa pada gangguan pendengaran akibat kebisingan yang selalau mengalami kecelakaan di akibatkan pekerjaan terbanyak kedua yang diderita seumur hidup manuasia. Gangguan pendengaran di akibatkan kebisingan yang terjadi secara tiba-tiba dalam hitungan detik maka secara perlahan dalam hitungan bulan dan sampai bertahun bahkan kadang kurang disadari oleh pekerja.

Berdasarkan terhadap uraian di atas maka kita perlu melakukan penelitian tentang pengaruh kebisingan terhadap gangguan pendengaran pekerja PT. PLN (Persero) unit PLTD Kelapa Lima Merauke (Pembangkit Listrik Tenaga Diesel). Adapun tujuan penulisan dari penelitian tingkat kebisingan adalah mengidentifikasi faktor resiko tingkat kebisingan terhadap pekerja pada PLTD Kelapa Lima Merauke. 


\section{TINJAUAN PUSTAKA}

2.1 Dasar Yuridis Keselamatan dan Kesehatan Kerja (K3)

Keselamatan dan Kesehatan Kerja (K3) merupakan hal yang paling penting karena menyangkut dengan hak dan kewajiban dari setiap pekerja dan perusahaan, untuk itu maka pemerintah Indonesia menetapkannya melalui rumusan undang-undang sebagai landasan hukum dalam pelaksanaannya, antara lain:

1. UU Nomor 13 tahun 2003 tentang Tenaga Kerja

2. UU Nomor 1 tahun 1970 tentang Keselamatan Kerja

3. UU Nomor 24 Tahun 2011 tentang BPJS tenaga Kerja

4. UU Nomor 23 tahun 1992 tentang Kesehatan

5. Surat Keputusan bersama antara Departemen Kesehatan dengan departemen lainnya yang berhubungan dengan Keselamatan dan kesehatan Kerja 7. Kepres RI No.22 tahun 1993 tentang Penyakit yang Timbul Karena Hubungan Kerja

6. Konvensi ILO No.185/1981 menetapkan kewajiban setiap warga negara untuk merumuskan, melaksanakan dan mengevaluasi kebijaksanaan nasionalnya dibidang kesehatan dan keselamatan kerja serta lingkungannya.

7. Konvensi ILO No.161 tahun 1985 tentang keselamatan kerja.

\subsection{Pengertian Keselamatan dan Kesehatan Kerja}

Merupakan bentuk suatu tindakan dan persepsi serta pengaplikasian yang dimaksudkan dengan tujuan agar setiap tenaga kerja dan manusia secara umum memperoleh suatu jaminan secara utuh dan sempurna baik jasmaniah maupun rohaniah. Keselamatan kerja adalah suatu proses dari berbagai macam proses yang mempunyai tujuan agar dapat menghadirkan kondisi serta suasana yang aman dan tenteram untuk setiap tenaga kerja ditempat kerja ketika sedang melaksanakan pekerjaan. Keselamatan kerja merupakan keadaan yang menggambarkan situasi keselamatan yang tidak mempunyai dampak resik terjadinya kecelakaan atau kerusakan di tempat kerja dimana mencakup pada kondisi bangunan, kondisi mesin, peralatan keselamatan, dan kondisi pekerja. Keselamatan selalu berpatokan pada bentuk perlindungan terhadap kondisi phisic dari pekerja agar terhindar dari kecelakaan yang diakibatkan dari aktivitas pekerja tersebut sehingga kesejahteraan phisic, phicis pekerja merasakan kesejahteraan. merujuk pada perlindungan terhadap kesejahteraan fisik seseorang terhadap cedera yang terkait dengan pekerjaan. Dengan demikian setiap pekerja dapat merasakan situasi dan kondisi kerja yang aman tetapi juga sehat, baik pengaruhnya terhadap perusahaan, para pekerja maupun lingkungan disekitar tempat kerja. Kesehatan dan keselamatan kerja menunjukkan kepada kondisi-kondisi fisiologis-fisikal dan psikologis tenaga kerja yang diakibatkan oleh lingkungan kerja yang disediakan oleh perusahaan. Sehingga dapat diambil kesimpulan bahwa keselamatan dan kesehatan kerja merupakan instrumen penting yang menjamin perlindungan terhadap para pekerja baik itu jaminan phisic maupun jaminan phicis terhadap tempat kerja juga semua peralatan penunjang maupun halhal lain yang saling terkait dengan pekerjaan yang dikerjakan oleh para pekerja dimana semua semua hasil karyanya bermanfaat bagi masyarakat. 


\subsection{Definisi Kebisingan}

Kebisingan merupakan salah satu faktor bahaya terhadap kesehatan pekerja dan dapat merusak sel saraf terhadap pendengaran pekerja, di mana dapat mempengaruhi pendengaran yaitu melalui gelombang longitudinal yang dapat menimbulkan getaran dari sumber kebisingan di mana bunyi dan gelombang yang akan merambat melalui udara atau penghantar lainnya, di dalam perlindungan terhadap kesehatan pekerja, bising yang sangat rentang mempengaruhi pekerja dari sumber bunyi biasanya dari alat produksi atau alat kerja yang pada tingkat tertentu dapat menimbulkan terganggunya pendengaran dan mana kalah suara yang tidak di sadari terhadap pekerja karna sangat terganggu pendengaran pekerja saat dalam ruangan yang rentang kebisingan (noise is unwanted sound).

Sedangkan di bagian kesehatan pekerja maka kebisingan ini juga menurunkan indra pendengaran perkerja, atau secara kualitatif (penyempitan pendengaran) ataupun kuantitatif (peningkatan ambang pendengaran), faktor intensitas kebisinga, frekuensi pada waktu tertentu.

Maka dapat disimpulkan bahwa bising yaitu suara yang tidak dikehendaki yang dapat menganggu kesehatan pekerja, kenyamanan serta dapat menimbukan gangguan pendengaran (ketulian).

\section{METODE PENELITIAN}

\subsection{Rancangan Penelitian}

Penelitian ini menggunakan metode pengumpulan data dilapangan dengan menggunakan wawancara dan sebaran kuisioner. Adapun lokasi untuk melaksanakan penelitian untuk memperoleh data yang berkaitan dengan permasalahan dalam penulisan ini bertempat Pembangkit
Listrik Tenaga Diesel (PLTD) Kelapa Lima jalan Brawijaya Merauke. Pelaksanaan penelitian akan direncanakan pada bulan Mei - Juni 2019.

\subsection{Pendekatan dan Jenis Penelitian}

Dalam penelitian ini jenis penelitian yang digunakan adalah jenis kuantitatif, dimana jenis kuantitatif merupakan penelitian yang berbentuk angka untuk menguji suatu hipotesis. Dalam penelitian kuantitatif, realitas dipandang sebagai sesuatu yang konkret dan dapat diamati dengan panca indra, dikategorikan menurut jenis, warna, bentuk dan perilaku, tidak berubah dan dapat diverifikasi.

Sedangkan pendekatan penelitian ini bersifat asosiatif, yaitu menggambarkan pola hubungan antara dua variabel atau lebih.

\subsection{Prosedur Pengumpulan Data}

Prosedur pengumpulan data dalam penelitian ini adalah sebagai berikut:

1. Observasi Observasi merupakan metode pengumpulan data melalui pengamatan kegiatan sehari-hari.

2. Kuesioner

Kuesioner merupakan metode pengumpulan data melalui penyebaran daftar pemyataan yang diajukan sehubungan dengan materi penelitian kepada responden (pekerja pada PLTD) yang telah terpilih.

3. Penelitian pustaka

Penelitian pustaka yaitu dengan menggunakan studi kepustakaan dan literatur-literatur lainnya yang ada hubungannya dengan penelitian yang dilakukan.

\subsection{Pengukuran Variabel}

Penelitian ini menggunakan skala likert. 
Skala Likert digunakan untuk mengukur sikap, pendapat, dan persepsi seseorang atau sekelompok orang tentang fenomena sosial.

Untuk keperluan analisis kuantitatif, maka jawaban itu dapat diberi skor sebagai berikut:

\section{Tabel 3.1. Skala Likert}

\begin{tabular}{|c|c|c|}
\hline Kategori & Kode & Skor \\
\hline Sangat Setuju & SS & $\mathbf{4}$ \\
\hline Setuju & S & $\mathbf{3}$ \\
\hline Tidak Setuju & TS & $\mathbf{2}$ \\
\hline Sangat Tidak Setuju & STS & $\mathbf{1}$ \\
\hline
\end{tabular}

Sumber: Sugiyono, 2010

\subsection{Teknik Analisis Data}

Teknik analisis data yang digunakan dalam penelitian ini adalah teknik analisis statistik yang perhitungannya dilakukan dengan menggunakan software SPSS 20.0 for window. Analisis ini bertujuan untuk menentukan seberapa besar pengaruh antara suatu variabel $\mathrm{X}$ dengan variabel Y. Dimana variabel $\mathrm{X}$ (variabel independen) adalah motivasi (X1), dan APD (X2). Sedangkan variabel Y (variabel dependen) adalah penyakitparu. Metode yang digunakan pada penelitian ini adalah sebagai berikut:

\subsection{Uji Kualitas Data}

Untuk melakukan uji kualitas data atas data primer ini, maka peneliti menggunakan uji validitas dan uji reliabilitas.

a. Uji Validitas

Validitas berasal dari kata validity yang mempunyai arti sejauh mana ketepatan dan kecermatan suatu alat ukur dalam melakukan fungsi ukuranya. Uji validitas digunakan untuk mengukur sah atau tidaknya suatu kuesioner. Dengan demikian suatu tes atau instrumen pengukuran dapat dikatakan mempunyai validitas yang tinggi apabila menghasilkan data yang relevan dengan tujuan pengukuran dan harus memberikan gambaran yang cermat mengenai data tersebut.

Ketentuan untuk menyatakan valid/tidak valid adalah dengan cara membandingkan antara hasil perhitungan data penelitian (rhitung) dengan ftabet dengan kriteria sebagai berikut:

Alpha : $5 \%$ (tingkat keyakinan)

$\mathrm{N} \quad$ : 30 (jumlah sampling)

df $\quad: \mathrm{N}-\mathrm{k}(30-2=28)$

$\mathrm{r}_{\text {tabel }}: 0,3061$ (dari table)

Keputusan:

a. Jika $\mathrm{r}_{\text {hitung }}>\mathrm{f}_{\text {tabel, }}$, berarti alat ukur $I$ indikator-indikator yang digunakan dinyatakan valid.

b. Jika $\mathrm{f}_{\text {hitung }}<\mathrm{f}_{\text {tabel}}$, berarti alat ukur $I$ indikator-indikator yang digunakan dinyatakan tidak valid.

\section{b. Uji Reliabilitas}

Reliabilitas adalah sejauh mana hasil suatu pengukuran dapat dipercaya dan dapat memberikan hasil yang relatif tidak berbeda apabila dilakukan kembali kepada subyek yang sama. Alat pengujian yang digunakan adalah koefisien alpha Cronbach dengan ketentuan :

a. Koefisien alpha Cronbach > 0,60, maka suatu variabel yang digunakan dinyatakan reliabel.

b. Koefisien alpha Cronbach < 0,60, maka suatu variabel yang digunakan dinyatakan tidak reliabel. 


\section{HASIL DAN PEMBAHASAN}

4.1. Hasil Analisis Data

\subsubsection{Uji Kualitas Data}

Variabel bebas dan terikat atau disebut juga variabel independen dan dependen adalah dua jenis variabel penelitian yang dapat digunakan peneliti untuk merumuskan hipotesis. Selain itu, juga dapat digunakan peneliti untuk membantu menyusun teori dan menjelaskan fenomena yang diteliti. Perbedaan antara variabel bebas dan terikat terletak pada hubungan antara keduanya. Variabel bebas adalah variabel yang mempengaruhi. Sedangkan variabel terikat adalah variabel yang dipengaruhi. variabel bebas atau variabel independen adalah variabel yang mempengaruhi variabel terikat atau variabel dependen. Dengan kata lain, variabel bebas adalah variabel yang mempengaruhi.

\subsubsection{Uji Validitas}

Berdasarkan hasil analisis data pada program software SPSS 20.0 for windows seperti terlihat di table 4.1 dimana dengan jumlah responden sebanyak 40 menunjukkan dengan nilai $\mathrm{N}=40$, taraf signifikansi 0,05 . Terlihat pada tabel bahwa nilai signifikasi adalah dibawah atau lebih kecil dari 0.05. Nilai r-tabel yang diperoleh, $\mathrm{df}=\mathrm{N}-2$, dimana jumlah responden, $\mathrm{N}=40$ sehingga $\mathrm{df}=\mathrm{N}(40)-2=38$. Dari Tabel $\mathrm{r}$ tabel diperoleh nilai df $38=0,3120$. Terlihat pada tabel bahwa nilai r-hitung dari $\mathrm{X} 1, \mathrm{X} 2, \mathrm{X} 3, \mathrm{X} 4, \mathrm{X} 5, \mathrm{X} 6, \mathrm{X} 7, \mathrm{X} 8, \mathrm{X} 9, \mathrm{X10}$, $\mathrm{X} 11$, lebih besar dari nilai df38 $=0,3120$. Maka dapat dikatakan bahwa r-hitung > rtabel, artinya bahwa semua nilai instrumen diatas dikatakan valid dan dapat digunakan dalam penelitian.

Pada tabel 4.2, dapat dilihat bahwa $\mathrm{N}$ $=40$, taraf signifikansi 0,05 . Terlihat pada tabel bahwa nilai signifikasi adalah dibawah atau lebih kecil dari 0.05. Nilai r-tabel yang diperoleh, $\quad \mathrm{df}=\mathrm{N}-2, \quad$ dimana jumlah responden, $\mathrm{N}=40$ sehingga $\mathrm{df}=\mathrm{N}(40)-2=$ 38. Dari Tabel r-tabel diperoleh nilai df $38=$ 0,3120 . Terlihat pada tabel bahwa nilai $r$ hitung dari Y1, Y2, Y3, Y4, Y5, lebih besar dari nilai df38 $=0,3120$. Maka dapat dikatakan bahwa r-hitung > r-tabel, artinya bahwa semua nilai instrumen diatas dikatakan valid dan dapat digunakan.

Terlihat bahwa untuk jumlah responden $\mathrm{N}=40$, usia dengan tingkat validitas 18-19 tahun 7.5 dan berturut-turut untuk 20-29 tahun, 30-39 tahun,

40-50 tahun adalah 57.5, 7.5 dan 27.5. Begitu juga untuk masa kerja dan tingkat pendidikan.

\subsubsection{Uji Reliabilitas}

Reliabilitas adalah sejauh mana hasil suatu pengukuran dapat dipercaya dan dapat memberikan hasil yang relatif tidak berbeda apabila dilakukan kembali kepada subyek yang sama. Untuk menetapkan suatu kuesioner reliabel atau tidak dengan menggunakan koefisien a $>0,60$. Tabel berikut menunjukkan hasil uji reliabilitas terhadap 40 responden.

Dapat dilihat bahwa variabel dependent dan independen dapat dikatakan reliabel karena nilai Cronbach's Alpha $\alpha>$ 0,60 yaitu untuk variabel terikat $X$ sebesar 0.724 atau $72.4 \%$ dan variabel bebas $\mathrm{Y}$ sebesar 0.888 atau $88.8 \%$. Sehingga dapat disimpulkan bahwa semua instrumen dalam penelitian ini dinyatakan reliabel.

Uji F dilakukan untuk mengetahui pengaruh variabel independen yang dimasukkan dalam model regresi secara individu terhadap variabel dependen. $F_{\text {hitung }}$ diperoleh sebesar 4,231 dengan tingkat 
signifikasi 0,047 dengan nilai

$F_{\text {tabel }}$ sebesar 3.24 dengan nilai signifikansi $\alpha=$ 5\%. Karena nilai $\mathrm{F}_{\text {hitung }}>\mathrm{F}_{\text {tabel }}$ (4.231> 3.24) dan nilai signifikansi diri sendiri dan APD terhadap pendengaran lebih besar daripada nilai signifikansi $a=5 \%(0,047<$ 0,05), maka Ha diterima dan Ho ditolah. Artinya secara bersama-sama (simultan) karakteristik responden dan alat pelindung diri (APD) berpengaruh positif dan signifikan terhadap pendengaran bagi petugas/operator di PLTD Kelapa Lima Merauke.

Persamaan regresi diatas mengandung makna bahwa:

a. Konstanta bernilai positif yaitu 21.294, ini berarti bahwa pengaruh hubungan kerja dan K3 secara umum dan K3 secara umum, maka akan mempengaruhi kesehatan kerja adalah 21.294.

b. Koefisien regresi variabel pengetahuan karyawan bemilai positif yaitu 0.666 , ini berarti bahwa jika terjadi peningkatan variabel kesehatan kerja sebesar satu satuan dengan asumsi variabel lain konstan, maka akan mempengaruhi kesehatan kerja akan naik sebesar 0.666 satuan.

\subsubsection{Hasil Uji Hipotesis}

Nilai koefisien determinasi Adjusted $R$ Square sebesar 0.200 pada tabel diatas menunjukkan bahwa besarnya kontribusi variabel bebas Alat Pelindung Diri (APD), terhadap efek pendengaran pekerja/operator di PLTD Kelapa Lima Merauke adalah sebesar 20\% sedangkan sisanya sebesar $80 \%$ dipengaruhi oleh faktor lain yang tidak disertakan dalam penelitian ini.

Uji t (Uji Parsial)

Uji $t$ statsitik dipergunakan untuk melihat pengaruh variabel dependen yaitu Diri sendiri (X1), Pendengaran (X2) secara parsial terhadap variabel independen APD (Y).

Uji $t$ menunjukan seberapa jauh pengaruh variabel independen terhadap variabel dependen. Berdasarkan hasil uji t pada tabel 4.5 diatas dapat dilihat bahwa nilai thitung diperoleh sebesar 2,057 dengan tingkat signifikansi sebesar 0,004 dan nilai ttabel sebesar 1.68385 dengan nilai signifikansi $\mathrm{a}=5 \%$. Karena nilai $\mathrm{t}_{\text {hitung }}>$ $t_{\text {tabel }}(2.057>1.68385)$ dan nilai signifikansi alat pelindung diri terhadap penyakit paru lebih kecil daripada nilai signifikansi $\mathrm{a}=$ $5 \%$ $(0,047<0,05)$, maka Ha diterima dan Ho ditolak.

Artinya secara parsial alat pelindung diri berpengaruh positif dan signifikan terhadap penyakit paru pada pekerja di tempat pengergajian kayu yang berada di distrik Merauke. Hasil uji $t$ untuk variabel lingkungan kerja memiliki nilai thitung sebesar 2,793 dengan tingkat signifikansi sebesar 0.008 dan nilai $t_{\text {tabe1 }}$ sebesar 1.68385 dengan nilai signifikansi a $=5 \%$. Karena nilai thitung $>$ ttabel $(2,793>$ 1,70113) dan nilai signifikansi diri sendiri terhadap penyakit paru kecil dari pada nilai signifikansi $\mathrm{a}=5 \% \quad(0,008<0,05)$, maka Ha diterima dan Ho ditolak. Artinya secara parsial lingkungan kerja berpengaruh positif dan signifikan terhadap pendengaran bagi petugas/operator di PLTD Kelapa Lima Merauke.

Koefisien regresi mencerminkan hubungan antar variabel independen dengan variabel dependen (Diri sendiri dan pendengaran). Tanda (+) berarti terdapat hubungan yang positif atau searah antar variabel independen dengan variabel dependen. Sedangkan tanda (-) berarti terdapat hubungan negatif atau tidak searah antara variabel independen dengan variabel dependen. 


\subsection{PEMBAHASAN}

1. Pengaruh Hubungan Kerja Terhadap Kesehatan Kerja

Hasil penelitian menunjukkan bahwa secara parsial hubungan kerja berpengaruh positif dan signifikan terhadap kesehatan kerja bagi petugas/operator di PLTD Kelapa Lima Merauke. Hal ini dapat dilihat dari nilai koefisien regresi yang bemilai positif yaitu 0.660 dan nilai $t_{\text {hitung }}$ lebih besar daripada nilai $\mathrm{t}_{\text {tabel }}(7.406>1,67203)$ pada tingkat signifikansi 5\%. Selain itu, nilai signifikansi hubungan kerja terhadap kesehatan kerja lebih kecil daripada nilai signifikansi $\alpha=5 \%$ $(0,000<0,05)$. Nilai koefisien regresi sebesar 0.660 menunjukkan bahwa jika terjadi peningkatan variabel hubungan kerja sebesar satu satuan maka besamya kesehatan kerjaakan naik sebesar 0.660 satuan dan ini yang menyebabkan meningkatnya kesehatan kerja bagi petugas/operator di PLTD Kelapa Lima Merauke.

2. Pengaruh APD Secara Umum Terhadap Pendengaran

Hasil penelitian menunjukkan bahwa secara parsial APD secara umum berpengaruh positif dan signifikan terhadap pendengaran bagi pekerja/operator PLTD Kelapa Lima Merauke. Hal ini dapat dilihat dari nilai koefisien regresi yang bernilai positif yaitu 0.666 dan nilai $t_{\text {hitung }}$ lebih besar daripada nilai $t_{\text {tabel }}(2.057>1.68385)$ pada tingkat signifikansi $5 \%$. Selain itu, nilai signifikansi hubungan APD terhadap kesehatan kerja bagi petugas/operator di PLTD Kelapa Lima Merauke lebih kecil dari pada nilai signifikansi $\mathrm{a}=5 \%(0,047<0,05)$. Nilai koefisien regresi sebesar 0.666 menunjukkan bahwa jika terjadi peningkatan variabel APD sebesar satu satuan maka besarnya pendengaran petugas/operator di PLTD Kelapa Lima Merauke akan naik sebesar 0.666 satuan dan ini yang menyebabkan gangguan pendengaran bagi petugas/operator di PLTD Kelapa Lima Merauke.

Hasil penelitian menunjukkan bahwa secara bersama-sama (simultan) hubungan APD dan pendengaran bagi petugas/operator di PLTD Kelapa Lima Merauke secara keseluruhan berpengaruh positif dan signifikan terhadap kemampuan pendengaran bagi petugas/operator di PLTD Kelapa Lima. Hal ini dapat dilihat dari nilai $F_{\text {hitung }}$ lebih besar daripada nilai $\mathrm{F}_{\text {tabel }}(4.231>3,24)$ pada tingkat signifikansi 5\%. Selain itu, nilai signifikansi APD dan pendengaran bagi petugas/operator di PLTD Kelapa Lima Merauke lebih kecil daripada nilai signifikansi $\alpha=$ $5 \%(0,047<0,05)$. Nilai koefisien determinasi (R2) yang diperoleh sebesar 0.158 yang berarti bahwa variabel dependen yaitu Diri sendiri dan pendengaran bagi petugas/operator di PLTD Kelapa Lima Merauke dapat dijelaskan oleh variabel independen APD sebesar $15.8 \%$. Sedangkan $84.2 \%$ sisanya dipengaruhi oleh variabel lain yang tidak dimasukkan dalam penelitian ini. Nilai konstanta bernilai positif yaitu 21,294 yang berarti bahwa terdapat pengaruh antara pendengaran bagi petugas/operator di PLTD Kelapa Lima Merauke dengan APD. 


\section{KESIMPULAN}

Berdasarkan Hasil penelitian yang telah diuraikan sebelumnya, maka dapat disimpulkan bahwa secara parsial hubungan Alat Pelindung Diri berpengaruh positif dan signifikan pendengaran bagi petugas/operator di PLTD Kelapa Lima Merauke, secara bersama-sama (simultan) hubungan Alat Pelindung Diri berpengaruh secara umum berpengaruh positif dan signifikan terhadap pendengaran bagi petugas/operator di PLTD Kelapa Lima Merauke.

\section{DAFTAR PUSTAKA}

[1] R. S. Ade Supriyatno, "Pengaruh Intensitas Kebisingan Lingkungan Kerja Terhadap Kariawan PT. PLN (Persero), PLTD Siantan Pontianak," pp. 1-15, 2018.

[2] T. Yuliyanti, H. K. Titisari, and S. Nurlela, "Seminar Nasional IENACO - 2016 ISSN : 2337 - 4349 Seminar Nasional IENACO - 2016 ISSN: 2337 - 4349," Semin. Nas. IENACO, pp. 541-548, 2017.

[3] D. Kesehatan, L. Fakultas, K. Masyarakat, and U. Airlangga, "Analisis dampak intensitas kebisingan terhadap gangguan pendengaran petugas," no. 2004, pp. 229-237, 2007.

[4] T. Manfaat, "Analisa tingkat dan dampak kebisingan pembangkit listrik tenaga diesel (pltd) terhadap pekerja dan masyarakat sekitar," vol. 3, pp. 145-152, 2013.

[5] S. I. Soraya, "Perancangan Perangkat Lunak Audiometer Nada Murni dan Tutur Untuk Diagnosis Pendengaran," ADLN Perpust. Univ. Airlangga, no. September, pp. 1-21, 2012.
[6] P. Fithri and I. Q. Annisa, "Analisis Intensitas Kebisingan Tempat Kerja pada Area Utilities Unit," vol. 12, no. 2, p. 278, 2015. 